\title{
POLYCYCLIC AROMATIC HYDROCARBONS IN THE ORGANIC PHASE EXTRACTED FROM CHARCOAL FOR BARBECUE ${ }^{1}$
}

Ananias Francisco Dias Júnior ${ }^{2 *}$, Carlos Rogério Andrade ${ }^{3}$, José Otávio Brito ${ }^{4}$, Simone Possedente Lira ${ }^{4}$, Azarias Machado de Andrade ${ }^{5}$ and Natália Dias de Souza ${ }^{5}$

\footnotetext{
${ }^{1}$ Received on 12.12.2015 accepted for publication on 11.10.2017.

${ }^{2}$ Universidade Federal do Espírito Santo, Departamento de Ciências Florestais e da Madeira, Jerônimo Monteiro, ES - Brasil. E-mail:<ananiasjr@usp.br>.

${ }^{3}$ Universidade Federal de Goiás, Curso de Engenharia Florestal, Jataí, GO - Brasil. E-mail: <crandrade@usp.br>.

${ }^{4}$ Universidade de São Paulo, Departamento de Ciências Florestais, Piracicaba, SP - Brasil. E-mail: <jobrito@usp.br>and <ssplira@usp.br>.

${ }^{5}$ Universidade Federal Rural do Rio de Janeiro, Departamento de Produtos Florestais, Seropedica, RJ - Brasil. E-mail: <azarias@ufrrj.br> and $<$ natdias@hotmail.com>.

*Corresponding author.
}

\begin{abstract}
Charcoal is a widely used product for barbecue, however, its quality for said use has not been well studied. Polycyclic aromatic hydrocarbons (PAHs) are a class of carcinogenic compounds that can be present in charcoal. Thus, the objective of this study was to analyze the organic phase extracted from charcoal by organic solvents, regarding the presence of PAHs. For this, a commercial charcoal brand was acquired, collected in establishments in the city of Piracicaba, São Paulo. Complementary tests were carried out to identify the wood used in the production of charcoal, such as determination of humidity, apparent density, immediate composition, calorific value, and combustion index. The organic phase extracted from the charcoal using cyclohexane was analyzed in a gas chromatograph coupled to a mass spectrometer (GC/MS) for identification of a class of sixteen PAHs. In general, charcoal presented regular characteristics for barbecue. All PAHs analyzed were detected in the organic phase extracted from the charcoal, but the observed values were below the quantified limit determined
\end{abstract}

Keywords: Quality of charcoal; Charcoal toxicity; Gas chromatography.

\section{HIDROCARBONETOS POLICÍCLICOS AROMÁTICOS NO COMPOSTO ORGÂNICO EXTRAÍDO DO CARVÃO VEGETAL UTILIZADO PARA COCÇÃO DE ALIMENTOS}

\begin{abstract}
RESUMO - O carvão vegetal é um produto bastante utilizado para a cocção de alimentos, porém, a sua qualidade para o referido uso não tem sido bem estudada. Os hidrocarbonetos policíclicos aromáticos (HPAs) são uma classe de compostos carcinógenos que podem estar presentes no carvão vegetal. Dessa forma, o objetivo deste estudo foi analisar o composto orgânico líquido extraído do carvão vegetal pela ação de solventes orgânicos, quanto à presença de HPAs. Para isso, foi adquirida uma marca comercial de carvão, coletada em estabelecimentos comercias em Piracicaba, SP. Foram realizados ensaios complementares para identificação da madeira utilizada na produção do carvão, determinação da umidade, densidade aparente, composição imediata, poder calorífico e índice de combustão. O composto orgânico extraído do carvão vegetal a partir da dissolução em ciclohexano foi analisado por meio de cromatografia a gás acoplado a um espectrômetro de massa (GC/MS), com intuito de determinar uma classe de dezesseis HPAs. De forma geral, o carvão vegetal apresentou características regulares para utilização em cocção de alimentos. Todos os HPAs analisados foram detectados no composto orgânico extraído do carvão, porém os valores observados estiveram abaixo do limite de quantificação determinado.
\end{abstract}

Palavras-Chave: Qualidade do carvão vegetal; Toxicidade do carvão vegetal; Cromatografia gasosa. 


\section{INTRODUCTION}

Brazil ranks as the largest producer and, at the same time, the largest consumer of charcoal in the world. On average, 6.6 million tons year-1 (Balanço Energético Nacional, 2015; Indústria Brasileira de Árvores, 2016) are produced, and almost $90 \%$ was destined for steel purposes, mainly in the Minas Gerais State. It is estimated that the remainder was mostly used in cooking food (barbecue).

The preparation of food based on firewood and charcoal is one of the oldest practices used by mankind (Warnes, 2008; Stumpe-Vîksna et al., 2008; Ledesma et al., 2016). Dias et al. (2015a) identified that in the residences of Piracicaba, SP, barbecue activities occur at least once a month. Barbecue is very widespread, involving sociocultural aspects, production methodologies, and a supply chain that includes, but is not limited to, logistics of distribution and collection (Warnes, 2008).

Despite the high Brazilian demand for charcoal, the country's official regulations only regulate testing procedures but do not assign minimum standards for the product intended for the barbecue. The only Brazilian mechanism that establishes guidelines for quality control of barbecue charcoal is the Secretary of Agriculture and Supply of the São Paulo State (SAA). The São Paulo - Premium Seal Charcoal (voluntary adhesion), promulgated by Resolution $n^{\circ}$. 10 SAA on July 11 , 2003 (São Paulo, 2003), was amended with Resolution $\mathrm{n}^{\circ} .40$ (São Paulo, 2015). In Europe, for example, Association Française de Normalisation (2005): Appareils, combustibles solides et allume-barbecue pour la cuisson au barbecue, normalizes minimum quality aspects for charcoal and briquettes to be used in the barbecue.

The standards cited, however, support only the regular characteristics of charcoal, while other particulars, such as the presence of potentially toxic compounds, are not taken into account. This is the case of polycyclic aromatic hydrocarbons (PAHs) carcinogenic compounds, which have received special attention from the World Health Organization (WHO), International Agency for Research on Cancer (IARC), and have been highlighted in several studies for their risk in food contamination (Mottier et al., 2000; Costa, 2001; Stumpe-Vîksna et al., 2008; Duedahl-Olesen et al., 2015; Ledesma et al., 2016). The maximum permitted levels of PAHs in certain food items are set by European legislation through the Regulatory Commission (CE) 208/2005 (European Union, 2005).

The charcoal used in the barbecue can contaminate the food through contact with the gases emitted containing PAHs, which in turn, cause its composition to be influenced by the raw combustion material and the process by which it was carbonized (Larsson, 1982; Nisha et al., 2015). According to Larsson (1982), these factors mainly influence the amount of residual tar remaining in the pores and are responsible for the formation of PAHs during the combustion of charcoal. Stumpe-Vîksna et al. (2008) analyzed foods prepared with charcoal from coniferous wood and obtained important contamination rates for PAHs in food. The PAH values can be substantially higher in coniferous wood charcoals due to the resin and, therefore, the type of charcoal chosen may be a determining factor in the levels of these contaminants (Larsson, 1982; Paz et al., 2017). In Brazil, the most recommended wood for charcoal production is of the genus Eucalyptus, but there are situations in which woods of other genera (cerrado biome) are used for this purpose.

Thus, the aim of this study was to analyze the organic phase extracted from charcoal by the action of organic solvents in the presence of potentially toxic polycyclic aromatic hydrocarbons (PAHs). Additionally, charcoal was evaluated for physical, mechanical, and immediate chemical characteristics.

\section{MATERIALAND METHODS}

\subsection{Sampling and characterization of charcoal}

In the city of Piracicaba, SP, $3 \mathrm{~kg}$ packages of " $\mathrm{A}$ " brand charcoal marketed for barbecue were collected. Sampling was carried out in twenty commercial establishments distributed in the 63 districts that compose the municipality. The establishments were chosen from a list provided by the Commercial and Industrial Association of Piracicaba, SP (ACIP). The justification for working with the charcoal acquired in the packaging for the retail trade was to guarantee the randomness of the sampling, different batches of the product, and to get as similar as possible to what is normally available to the final consumer. The collected materials were submitted to the following initial analyses:

- Identification of the wood group that for the charcoal source (Rangel, 2012; Vital et al., 2014).

Revista Árvore. 2017;41(5):e410510

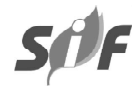


-Moisture (\%)-ASTMD 1762-84(American Society For Testing and Materials, 1977).

- Bulk density $\left(\mathrm{g} \mathrm{cm}^{-3}\right)$ - NBR 11941 (Associação Brasileira de Normas Técnicas, 2003).

- Friability (\%) - NBR 8740 (Associação Brasileira de Normas Técnicas, 1985).

- Immediate composition: volatile content, ash content, and fixed carbon content (\%) - ASTM D 176284 (American Society For Testing and Materials, 1977).

- High calorific value and lower calorific value $\left(\mathrm{kcal} \mathrm{kg}^{-1}\right.$ ) - NBR 8633 (Associação Brasileira de Normas Técnicas, 1984).

- Charcoal combustion index - Dias et al. (2015b).

\subsection{Polycyclic aromatic hydrocarbons (PAHs)}

The preparation of the samples and the determination of the PAHs in the organic phase extracted from the charcoal were carried out according to the norms of the Environmental Protection Agency (EPA) methods 3550 C (US Environmental Protection Agency, 2007a) and EPA 8270 D(US Environmental Protection Agency, 2007b), respectively. Thus, samples composed of charcoal were dried in an oven at $105 \pm 3{ }^{\circ} \mathrm{C}$, then macerated and incorporated in a volumetric flask containing 100 $\mathrm{ml}$ of distilled water and $100 \mathrm{ml}$ of cyclohexane solvent. $250 \mathrm{ml}$ of ethanol was added to separate the water from the mixture. Then, $50 \mathrm{ml}$ dimethylformaldehyde solvent was added to facilitate separation of the cyclohexane from the organic phase extracted from charcoal. The extraction procedure was performed using the solid phase technique with the following conditions: sohxlet solvent, temperature of $60{ }^{\circ} \mathrm{C}$, and the final organic phase was concentrated in a rotary evaporator.

The limits of detection (LD) and quantification (LQ) were calculated based on the signal noise ratio from standard solution analyses, assuming a ratio of 10:1 for LQ and 3:1 for LD. Calibration curves were constructed from the addition of known volumes of stock solution of a class of 16 PAHs (Table 1) in an isopropanol and ethyl acetate (1:1) solution.

The chromatographic analyses were performed using a gas chromatograph, Thermo Scientific DSQ II model, coupled to a mass spectrometer (GC/MS). This spectrometer assembly included a 5\% capillary column of phenyl methylsiloxane type (20 m; ID 180
Table 1 - Compounds analyzed in the charcoal.

Tabela 1 - Compostos analisados no carvão vegetal.

\begin{tabular}{lccc}
\hline Hydrocarbon & $\mathrm{ID}$ & $\mathrm{CAS}$ & Carcinogenicity \\
\hline Acenaphthene & $\mathrm{Ac}$ & $83-32-9$ & $\mathrm{U}$ \\
Acenaphthylene & $\mathrm{Ap}$ & $208-96-8$ & $\mathrm{U}$ \\
Anthracene & $\mathrm{A}$ & $120-12-7$ & $\mathrm{U}$ \\
Benzo[a]anthracene & $\mathrm{BaA}$ & $56-55-3$ & $\mathrm{~S}$ \\
Benzo(a)pyrene & $\mathrm{BaP}$ & $50-32-8$ & $\mathrm{~S}$ \\
Benzo[b]fluoranthene & $\mathrm{BbF}$ & $205-99-2$ & $\mathrm{~S}$ \\
Benzo[g,h,i]perylene & $\mathrm{BghiP}$ & $191-24-2$ & $\mathrm{U}$ \\
Benzo[k]fluoranthene & $\mathrm{BkF}$ & $207-08-9$ & $\mathrm{~S}$ \\
Chrysene & $\mathrm{Ch}$ & $218-01-9$ & $\mathrm{~S}$ \\
Dibenz[a,h]anthracene & $\mathrm{DBahA}$ & $53-70-3$ & $\mathrm{~S}$ \\
Phenanthrene & $\mathrm{Pa}$ & $85-01-8$ & $\mathrm{U}$ \\
Fluoranthene & $\mathrm{F} 1$ & $206-44-0$ & $\mathrm{~N}$ \\
Fluorene & $\mathrm{F}$ & $86-73-7$ & $\mathrm{U}$ \\
Indeno[1,2,3-cd]pyrene & $\mathrm{IP}$ & $193-39-5$ & $\mathrm{~S}$ \\
Naphthalene & $\mathrm{Na}$ & $91-20-3$ & $\mathrm{U}$ \\
Pyreno & $\mathrm{P}$ & $129-00-0$ & $\mathrm{~N}$ \\
\hline
\end{tabular}

Wherein: ID = hydrocarbon abbreviation; CAS $=$ registration on Chemical Abstract Service, designated to substances in a sequential manner; each CAS record number is a unique numeric identifier. Data available for evidence of effect: (S) Sufficient; (U) Unlimited; (N) Non-carcinogenic. Source: adapted from Pereira et al. (2000).

$\mu \mathrm{m} ;$ Film $0.18 \mu \mathrm{m})$ and was equipped with entraining Helium gas, in addition to using an initial temperature of $60^{\circ} \mathrm{C}$ and maximum temperature of $350^{\circ} \mathrm{C}$ during a twenty minute running time. The equipment was programmed for complete scan analysis, run time of 0.13 seconds, and eight sweeps per second. For the analysis, one microliter $(1 \mu 1)$ of the organic phase was injected into the chromatograph. The data was acquired in the selected ion monitoring mode (GC/MS). Peak spectra were compared to the mass spectra of the PAH standards and equipment library.

\subsection{Data analysis}

The data obtained for the physical, mechanical, and immediate chemical properties of charcoal were analyzed using descriptive statistics, considering the mean values and their respective standard errors. The chromatographic results were interpreted by the values provided by GC/MS and chromatograms generated.

\section{RESULTS}

The charcoal ("A") was identified as having originated from Eucalyptus spp wood. The methodologies used in this research allow for the recognition of wood only at the genus level, differentiating whether the charcoal originated from eucalyptus or another genus. However, the result

Revista Árvore. 2017;41(5):e410510 
represents a significant contribution to the study proposal. Table 2 presents the mean values of the other characteristics analyzed.

The charcoal analyzed presented regular values for the evaluated characteristics, being shown to be satisfactory for use in barbecue. These values are in accordance with those proposed by the Charcoal Premium Resolution (São Paulo, 2015), Association Française de Normalisation (2005) and Dias et al. (2015a, 2015b), all presenting standards and specific studies for charcoal used in barbecue.

Table 3 presents the equations obtained after the calibrations of the 16 PAHs analyzed in the organic phase extracted from the charcoal and the respective coefficients of determination $\left(\mathrm{R}^{2}\right)$.

It is observed that the $\mathrm{R}^{2}$ values ranged between 0.9990 and 0.9998 , indicating good correlations between the retention area and the concentration of the calibrated PAHs. These results demonstrate the accuracy and reliability of determination of the compounds in this study. According to Table 4, the PAH values detected in the organic charcoal phase were below $0.32 \mathrm{mg} \mathrm{kg}^{-1}$.

\section{DISCUSSION}

For barbecue, high humidity values can compromise the ignition and combustion of charcoal. High friability levels indicate greater ease of breakage during transport and handling, and high fixed carbon contents indicate greater combustion capacity without the generation of flames.

The charcoal had high fixed carbon content, consistent with previously observed combustion performance (Table 2). The combustion index (ICOM ${ }_{\mathrm{cv}}$ ) considers the time and mass loss for temperatures above $150^{\circ} \mathrm{C}$. Thus, a greater $\mathrm{ICOM}_{\mathrm{cv}}$ is observed with more constant temperature, as a function of the lower mass loss. However, high ash percentage is an undesirable characteristic in charcoal, since it interferes negatively in its calorific value (Oliveira et al., 2010).
Brito (2002), São Paulo (2015), and Rosa et al. (2012) consider that charcoal of good quality for barbecue must have certain characteristics, such as high bulk density, high fixed carbon content $(>75 \%)$, high calorific value, low humidity $(<5 \%)$, low volatile $(<25 \%)$, and low ash content $(<1,5 \%)$.

With respect to PAHs, the chromatogram (Figure 1) obtained evidences the presence of the 16 PAHs analyzed in the organic phase extracted from charcoal "A".

The detection of hydrocarbons indicates that contamination of food during barbecue should be considered. Although PAHs have been identified in the organic phase extracted from charcoal, it contains residual tar (PAHs precursor) that can be volatilized and incorporated into the food during grilling. Considering that charcoal is not a material of welldefined molecular chemical composition (structures of the carbon chains), carbonization is based on the elimination of volatile components of wood by heat action, in order to concentrate carbon (Perez et al., 2004; Francioso et al., 2011). For barbecue, greater carbon content is better, as this would result in lower concentrations of residual tar in its pores and, consequently, lower levels of PAHs.

The fixed carbon content is an important indicator of charcoal quality and, therefore, it can be related to PAHs. This is true because the fixed carbon content of the charcoal increases as the temperature increases during the carbonization process (Trugilho and Silva, 2001; Dias et al., 2016). The result would be, for example, charcoal with lower tar yields as compared to charcoal produced at a lower final carbonization temperature.

Noting the charcoal " $A$ " characteristics, it was determined that all or parts of the PAHs analyzed were not detected, especially considering their high fixed carbon content ( $80.91 \%$, Table 2$)$. Thus, charcoal is a product that can be toxic, and further studies should be conducted to better characterize the material in relation to other aspects involving the production and use of charcoal for food preparation purposes. This argument

Table 2 - Average values of the characteristics analyzed in the charcoal.

Tabela 2 - Valores médios das características analisadas no carvão vegetal.

\begin{tabular}{|c|c|c|c|c|c|c|c|c|c|}
\hline Trademark & $\mathrm{M}$ & $\mathrm{F}$ & $\mathrm{BD}$ & VM & $\mathrm{A}$ & FC & $\mathrm{ICOM}_{\mathrm{c}}$ & $\mathrm{HCV}$ & LCV \\
\hline “A" & 5,32 & 23,36 & 0,345 & 18,37 & 0,72 & 80,91 & 0,59 & 8731 & 8163 \\
\hline S.E. & 0,012 & 3,001 & 0,033 & 1,074 & 0,364 & 0,738 & 0,015 & 59,001 & 54,931 \\
\hline
\end{tabular}

Revista Árvore. 2017;41(5):e410510 
Table 3 - Calibration equations obtained for hydrocarbons analyzed.

Tabela 3 - Equações de calibrações obtidas para os hidrocarbonetos analisados.

\begin{tabular}{lcc}
\hline Hydrocarbon & Calibration Equation & $\mathrm{R}^{2}$ \\
\hline Acenaphthene & $\mathrm{y}=44783.5 \mathrm{x}$ & 0.9992 \\
Acenaphthylene & $\mathrm{y}=67255 \mathrm{x}$ & 0.9991 \\
Anthracene & $\mathrm{y}=67876.9 \mathrm{x}$ & 0.9993 \\
Benzo[a]anthracene & $\mathrm{y}=78340.6 \mathrm{x}$ & 0.9998 \\
Benzo(a)pyrene & $\mathrm{y}=39624.5 \mathrm{x}$ & 0.9992 \\
Benzo[b]fluoranthene & $\mathrm{y}=43701.1 \mathrm{x}$ & 0.9990 \\
Benzo[g,h,i]perylene & $\mathrm{y}=55105.4 \mathrm{x}$ & 0.9993 \\
Benzo[k]fluoranthene & $\mathrm{y}=50461.3 \mathrm{x}$ & 0.9991 \\
Chrysene & $\mathrm{y}=74284.8 \mathrm{x}$ & 0.9992 \\
Dibenz[a,h]anthracene & $\mathrm{y}=37741.2 \mathrm{x}$ & 0.9998 \\
Phenanthrene & $\mathrm{y}=-178757+66358.6 \mathrm{x}$ & 0.9994 \\
Fluoranthene & $\mathrm{y}=74371.2 \mathrm{x}$ & 0.9994 \\
Fluorene & $\mathrm{y}=65045 \mathrm{x}$ & 0.9992 \\
Indeno[1,2,3-cd]pyrene & $\mathrm{y}=51607.5 \mathrm{x}$ & 0.9990 \\
Naphthalene & $\mathrm{y}=43788.1 \mathrm{x}$ & 0.9992 \\
Pyreno & $\mathrm{y}=76653.8 \mathrm{x}$ & 0.9992 \\
\hline Wherein: $\mathrm{y}=$ HPA retention area analyzed; $\mathrm{x}=\mathrm{HPA}$ concentration
\end{tabular}
(ppb).

is made because according to Duedahl-Olesen et al. (2015), any amount of PAHs in food is already a dangerous aspect for those who consume it.

The detected PAHs ranged from the simplest (in terms of the aromatic chain, such as naphthalene) to the more complex, such as (benzo[g,h,i]perylene). According to Larsson (1982), the way in which combustion is conducted during barbecue is a determining factor for the formation and elimination of PAHs. For the author, factors such as charcoal humidity, temperature, and aeration (load flow) of combustion equipment, can denature (low humidity and high temperature) the compounds by converting them to less harmful compounds. Therefore, it is recommended that barbecue be performed with high temperatures and with the food as far as possible from the heat source (charcoal) to lower exposure to PAHs (Larsson, 1982).

Based on a request from the European Commission (European Food Safety Authority, 2008), the Scientific Opinion of The Panel On Contaminants in The Food Chain groups toxicity levels into two categories of PAHs in foods. The first comprises four hydrocarbons: benzo[a]anthracene, benzo[a]pyrene, benzo[k]fluoranthene, and chrysene, and notes a recommended maximum intake of these compounds (per person) of less than $0.34 \mathrm{mg} \mathrm{kg}^{-1}$ per day. The recommended maximum intake of these compounds (per person) of less than $0.34 \mathrm{mg} \mathrm{kg}^{-1}$ per day. The second category consists of eight priority hydrocarbons, namely benzo[a]anthracene, benzo[a]pyrene, benzo[k]fluoranthene, benzo[g,h,i]perylene, benzo[a]pyrene, chrysene, dibenz[a,h]anthracene, and indeno[1,2,3-cd]pyrene (Wenzl et al., 2006). For this group, the daily intake of PAHs in grilled foods per person should not exceed $0.49 \mathrm{mg} \mathrm{kg}^{-1}$ per day.

These recommendations were established based on food intake, considering a high frequency of barbecue in Brazil, and the results obtained in this study. It can be established that the charcoal quality should also be evaluated for the food observed and studied. StumpeVîksna et al. (2008) detected values between $0.84 \mu \mathrm{g}$ $\mathrm{kg}^{-1}$ (dibenz[a,h]anthracene) and $17.69 \mu \mathrm{g} \mathrm{kg}^{-1}$ (chrysene) in charcoal grilled foods (meats and vegetables) from Latvia (Eastern Europe). Although they were of low magnitude, these values were considered by the authors as potential food contaminants and harmful to occupational health. The authors also found values below the detection limit for dibenz $[\mathrm{a}, \mathrm{h}]$ anthracene and benzo[a]pyrene.

Duedahl-Olesen et al. (2015) affirmed that the reduction of food contamination by PAHs can still be achieved by the consumption of meats with low levels of lipids (fats), preparation of food more than $20 \mathrm{~cm}$

Table 4 - PAHs detected in the charcoal.

Tabela 4-HPAs detectados no carvão vegetal.

\begin{tabular}{lcc}
\hline Hydrocarbon & \multicolumn{2}{c}{ Analytical Results $\left(\mathrm{mg} \mathrm{kg}^{-1}\right)$} \\
\cline { 2 - 3 } & Charcoal “A” & $\mathrm{LQ}$ \\
\hline Acenaphthene & $<\mathrm{LQ}$ & 0,32 \\
Acenaphthylene & $<\mathrm{LQ}$ & 0,32 \\
Anthracene & $<\mathrm{LQ}$ & 0,32 \\
Benzo[a]anthracene & $<\mathrm{LQ}$ & 0,32 \\
Benzo[a]pyrene & $<\mathrm{LQ}$ & 0,32 \\
Benzo[b]fluoranthene & $<\mathrm{LQ}$ & 0,32 \\
Benzo[g,h,i]perylene & $<\mathrm{LQ}$ & 0,32 \\
Benzo[k]fluoranthene & $<\mathrm{LQ}$ & 0,32 \\
Chrysene & $<\mathrm{LQ}$ & 0,32 \\
Dibenz[a,h]anthracene & $<\mathrm{LQ}$ & 0,32 \\
Phenanthrene & $<\mathrm{LQ}$ & 0,32 \\
Fluoranthene & $<\mathrm{LQ}$ & 0,32 \\
Fluorene & $<\mathrm{LQ}$ & 0,32 \\
Indeno[1,2,3-cd]pyrene & $<\mathrm{LQ}$ & 0,32 \\
Naphthalene & $<\mathrm{LQ}$ & 0,32 \\
Pyreno & $<\mathrm{LQ}$ & 0,32 \\
\hline
\end{tabular}

Wherein: $L Q=$ limit of detection of chemical compound. 
Wherein: $\mathrm{Ac}=$ Acenaphthene; $\mathrm{Ap}=$ Acenaphthylene; $\mathrm{A}=$ Anthracene; $\mathrm{BaA}=\mathrm{Benzo}[\mathrm{a}]$ anthracene; $\mathrm{BaP}=\mathrm{Benzo}(\mathrm{a}) \mathrm{pyrene} ; \mathrm{BbF}=\mathrm{Benzo}[\mathrm{b}]$ fluoranthene; $\mathrm{BghiP}=\mathrm{Benzo}[\mathrm{g}, \mathrm{h}, \mathrm{i}]$ perylene; $\mathrm{BkF}=\mathrm{Benzo}[\mathrm{k}]$ fluoranthene; $\mathrm{Ch}=\mathrm{Chrysene} ; \mathrm{DBahA}=\mathrm{Dibenz}[\mathrm{a}, \mathrm{h}]$ anthracene; Pa $=\mathrm{Phenanthrene} ; \mathrm{Fl}=$ Fluoranthene; $\mathrm{F}=$ Fluorene; IP = Indeno[1,2,3-cd]pyrene; $\mathrm{Na}=$ Naphthalene; $\mathrm{P}=$ Pyreno.

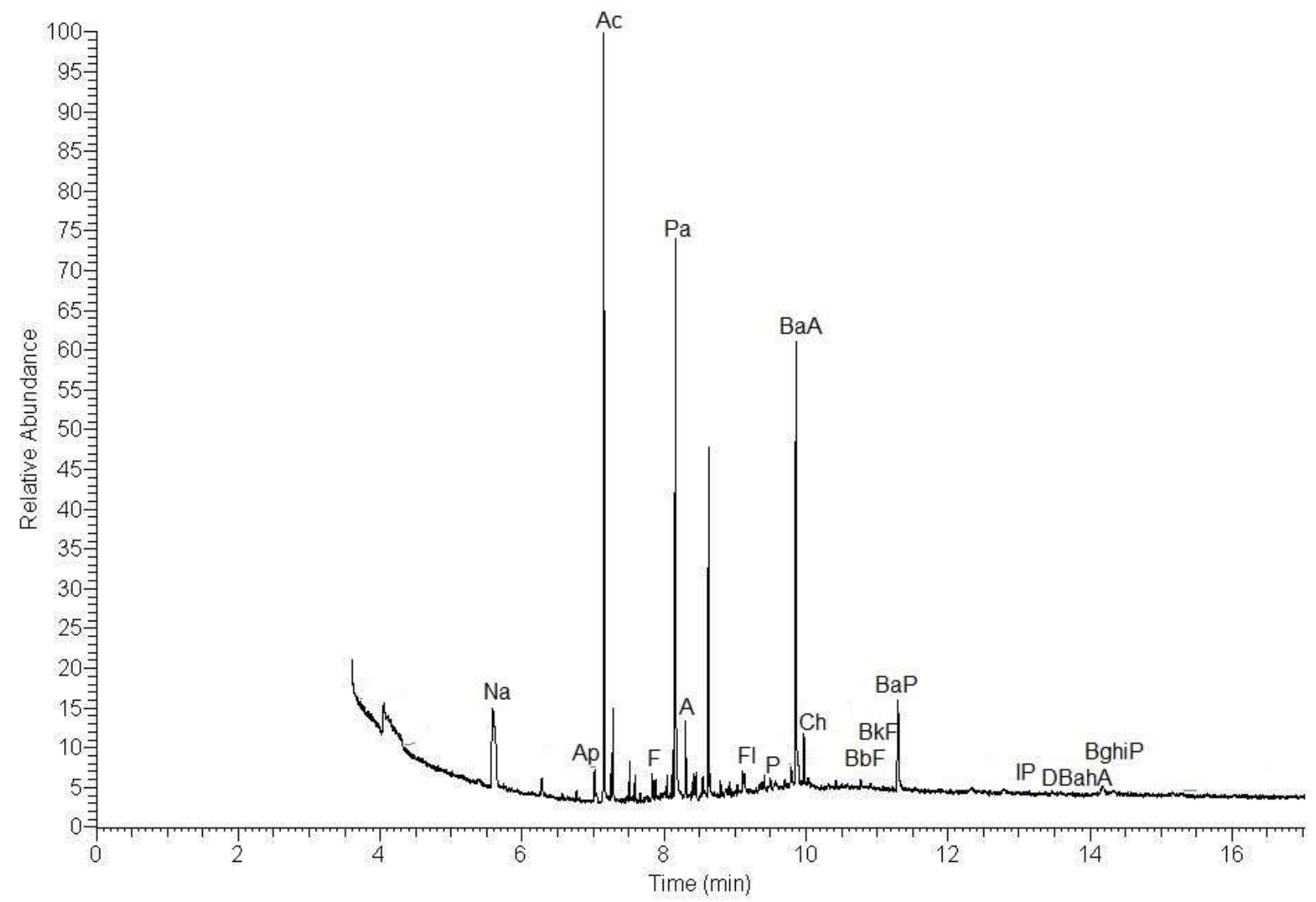

Figure 1 - Chromatogram obtained for PAHs analyzed.

Figura 1-Cromatograma obtido para os HPAs analisados.

away from the heat source (charcoal), maintaining of high cooking temperatures (through aeration and fuel feedback), avoiding the presence of flames (volatile materials), and direct contact with food. In practice, it is difficult to adopt the recommendations made by the authors, and the quality control of the product is the best prevention with respect to contamination by PAHs.

Regulation CE-208 (2005) establishes that the maximum level is $5.0 \mathrm{ng} \mathrm{g}^{-1}$ of benzo(a)pyrene (main indicator of PAHs) for meats and smoked and/or grilled products. It is considered that the limits recommended by the legislation refer specifically to food products, given that most studies define PAHs contamination pathways as: food composition and preparation processes (Mottier et al., 2000). In barbecue, charcoal comes into contact with food through contact with gases and particulates. In view of the whole context presented in this study, the research on charcoal may indicate more precisely the main contaminating agent: charcoal, food, or the variables of the barbecue process.

\section{CONCLUSIONS}

Charcoal "A" presented the recommended characteristics and parameters for barbecue.

The 16 standard PAHs in organic phase extracted from charcoal were detected, all at levels below 0.32 $\mathrm{mg} \mathrm{kg}^{-1}$.

Revista Árvore. 2017;41(5):e410510 
Further research is recommended for the qualification and quantification of PAHs in charcoal produced under different process conditions (raw material, carbonization temperature, and heating rate), grilling properties (distance from heat source, temperature variation, load flow), and the prepared foods. Analysis of the gases emitted by the combustion of charcoal by appropriate methodology (GC/PY) is also recommended in order to verify if the PAHs present in the organic phase extracted from the charcoal correspond to the same PAHs present in the emitted gases (qualitative and quantitative study).

\section{ACKNOWLEDGEMENTS}

The authors acknowledge the Brazilian Government Agency of Coordination for the Improvement of Higher Education Personnel (CAPES), the Institute of Forestry Research and Studies (IPEF), and the National Council for Scientific and Technological Development (CNPq/ 142075/2016-7) for the scholarship grants awarded. We would also like to thank Michael James Stablein of the University of Illinois Urbana-Champaign for his translation and English revision services in this research.

\section{REFERENCES}

American Society For Testing and Materials. ASTM D 1762-84: standard method for chemical analyses of wood charcoal. Philadelphia: ASTM; 1977. $1042 \mathrm{p}$.

Associação Brasileira de Normas Técnicas. NBR 8633: carvão vegetal: determinação do poder calorífico. Rio de Janeiro: ABNT; 1984. 12 p.

Associação Brasileira de Normas Técnicas. NBR 8740: carvão vegetal: determinação do índice de quebra e abrasão. Rio de Janeiro ABNT; 1985. 4 p.

Associação Brasileira de Normas Técnicas. NBR 11941: madeira: determinação da densidade básica. Rio de Janeiro: ABNT; 2003. 6 p.

Association Française de Normalisation. NF EM 1860-2: appareils, combustibles solides et allume: barbecue pour la cuisson au barbecue. SaintDenis: AFNOR; 2005. 29 p.

Balanço Energético Nacional. Empresa de Pesquisa Energética. Relatório anual: ano base 2014. Brasília: BEN; 2015 [cited 2017 Jun 22]. Available from: https://ben.epe.gov.br/downloads/ Relatorio_Final_BEN_2016.pdf
Brito JO. A escolha certa do carvão. Revista Churrasco e Churrascarias. 2002;5(24):16.

Costa AF. Avaliação da contaminação humana por hidrocarbonetos policíclicos aromáticos: determinação de 1-hidroxipireno urinário [dissertação]. Rio de Janeiro: Fundação Oswaldo Cruz, Escola Nacional de Saúde Pública; 2001. 80 p.

Dias AF Jr, Andrade CR, Brito JO, Milan M. Desdobramento da função qualidade na avaliação da qualidade do carvão vegetal utilizado para cocção de alimentos. Floresta e Ambiente. 2015a;22(2):262-70. http://dx.doi.org/10.1590/21798087.105314

Dias AF Jr, Brito JO, Andrade CR. Granulometric influence on the combustion of charcoal for barbecue. Rev Árvore. 2015b;39(6):1127-33. http:// dx.doi.org/10.1590/0100-67622015000600016.

Dias AF Jr, Pirola LP, Takeshita S, Lana AQ, Brito JO, Andrade AM. Higroscopicity of charcoal produced in different temperatures. Cerne. 2016;22(4):423-30. http://dx.doi.org/10.1590/ 01047760201622032175 .

Duedahl-Olesen L, Aaslyng M, Meinert L, Christensen T, Jensen AH, Binderup ML. Polycyclic Aromatic Hydrocarbons (PAH) in Danish barbecued meat. Food Control. 2015;57:169-76. http://dx.doi.org/10.1016/ j.foodcont.2015.04.012.

European Food Safety Authority. Polycyclic aromatic hydrocarbons in food. EFSA J. 2008;(724):1-114.

European Union. Directiva 2004/107/CE do Parlamento Europeu e do Conselho de 15 de Dezembro de 2004 relativa ao arsénio, ao cádmio, ao mercúrio, ao níquel e aos hidrocarbonetos aromáticos policíclicos no ar ambiente. Jornal Oficial da União Europeia [Internet], Bruxelas, 26 de janeiro de 2005 [cited 2017 Jun 22]. Available from: http://eur-lex.europa.eu/LexUriServ/ LexUriServ.do?uri=OJ:L:2005:023:0003:0016:PT:PDF

Francioso O, Sanchez-Cortes S, Bonora S, Roldán ML, Certini G. Structural characterization of charcoal size-fractions from a burnt Pinus pinea forest by FT-IR, Raman and surface-enhanced 
Raman spectroscopies. J Mol Struct. 2011;994(13):155-62. http://dx.doi.org/10.1016/ j.molstruc.2011.03.011.

Indústria Brasileira de Árvores. Relatório Anual IBÁ. Brasília: IBÁ; 2016 [cited 2017 Jun 22]. Available from: http://iba.org/images/shared/ Biblioteca/IBA_RelatorioAnual2016_.pdf

Larsson BK. Polycyclic aromatic hydrocarbons in smoked fish. Z Lebensm Unters Forsch. 1982;174(2):101-7. http://dx.doi.org/10.1007/ BF01045823.

Ledesma E, Rendueles M, Diaz M. Contamination of meat products during smoking by polycyclic aromatic hydrocarbons: processes and prevention. Food Control. 2016;60:64-87. http://dx.doi.org/ 10.1016/j.foodcont.2015.07.016.

Mottier P, Parisod V, Turesky RJ. Quantitative Determination of Polycyclic Aromatic Hydrocarbons in Barbecued Meat Sausages by Gas Chromatography Coupled to Mass Spectrometry. J Agric Food Chem. 2000;48(4):11606. http://dx.doi.org/10.1021/jf991205y. PMid:10775366.

Nisha AR, Dinesh Kumar V, Arivudainambi S, Umer M, Khan MS. Polycyclic aromatic hydrocarbons in processed meats: a toxicological perspective. Res J Chem Environ. 2015;19(6):72-6.

Oliveira AC, Carneiro ACO, Vital BR, Almeida W, Pereira BLC, Cardoso MT. Parâmetros de qualidade da madeira e do carvão vegetal de Eucalyptus pellita F. Muell. Sci For. 2010;38(87):431-9.

Paz APS, Nascimento ECP, Marcondes HC, Silva MCF, Hamoy M, Mello VJ. Presença de hidrocarbonetos policíclicos aromáticos em produtos alimentícios e a sua relação com o método de cocção e a natureza do alimento. Braz J Food Technol. 2017;20(0):e2016102. http:// dx.doi.org/10.1590/1981-6723.10216.

Pereira AD No, Moreira JC, Dias AEXO, Arbilla G, Ferreira LFV, Oliveira AS,. Avaliação da contaminação humana por hidrocarbonetos policíclicos aromáticos (HPAS) e seus derivados nitratos (NHPAS): uma revisão metodológica. Quim Nova. 2000;23(6):765-73. http://dx.doi.org/ 10.1590/S0100-40422000000600010.
Perez JAG, Vila FJG, Almendros G, Knicler H. The effect offire on soil organic matter: a review. Enviromental Internacional. 2004;30(6):855-70.

Rangel AA. Anatomia comparada do lenho e do carvão aplicada na identificação de 76 espécies da Amazônia no estado do Pará, Brasil [dissertação]. Piracicaba: USP, Escola Superior de Agricultura "Luiz de Queiroz"; 2012. 249 p.

Rosa RA, Arantes MDC, Paes JB, Andrade SP, Moulin JC. Qualidade do carvão vegetal para uso doméstico. J Biotechnol Biodivers. 2012;3(2):41-8.

São Paulo. Secretaria de Agricultura e Abastecimento de São Paulo. Resolução n ${ }^{\circ} 10$ SAA, de 11 de julho de 2003. Diário Oficial do Poder Executivo, São Paulo, julho de 2003.

São Paulo. Secretaria de Agricultura e Abastecimento. Resolução no 40 SAA, de 14 de dezembro de 2015. Diário Oficial do Poder Executivo, São Paulo, dezembro de 2015.

Stumpe-Vîksna I, Bartkeviès V, Kukâre A, Morozovs A. Polycyclic aromatic hydrocarbons in meat smoked with different types of wood. Food Chem. 2008;110(3):794-7. http://dx.doi.org/10.1016/ j.foodchem.2008.03.004.

Trugilho PF, Silva DA. Influência da temperatura final de carbonização nas características físicas e químicas do carvão vegetal de jatobá (Himenea courbaril L.). Sci Agrar. 2001;2(1):45-53. http:// dx.doi.org/10.5380/rsa.v2i1.976.

US Environmental Protection Agency. Method 3550 C: ultrasonic extraction. Washington: EPA; 2007a. 17 p.

US Environmental Protection Agency. Method 8270 D: semivolatile organic compounds by gas chromatography/mass spectrometry (GC/MS). Washington: EPA; 2007b. 70 p.

Vital BR, Carneiro AC, Cruz FM, Ribeiro KVG, Loures NG, Nacif AP. Manual de identificação de carvão vegetal. Viçosa: Ed. UFV; 2014. 163 p.

Warnes A. Savage barbecue: race, culture and the invention of america's first food. Geórgia: British Library; 2008. 201p.

Revista Árvore. 2017;41(5):e410510 
Wenzl T, Simon R, Anklam E, Kleiner J. Analytical methods for polycyclic aromatic hydrocarbons (PAHs) in food and the environment needed for new food legislation in the European Union. Trends Analyt Chem. 2006;25(7):716-25. http:// dx.doi.org/10.1016/j.trac.2006.05.010. 